\title{
The use of reflectance values for the interpretation of natural and anthropogenic charcoal assemblages
}

\author{
Laura C. McParland • Margaret E. Collinson • \\ Andrew C. Scott • Gill Campbell
}

Received: 23 June 2009 / Accepted: 13 September 2009/Published online: 13 October 2009

(C) Springer-Verlag 2009

\begin{abstract}
Charcoal assemblages occur in both natural and archaeological settings. Cell wall reflectance values of charcoal in polished blocks under oil provide a proxy for temperature of formation. This paper aims to (1) determine whether wildfire charcoals and anthropological charcoals from various pyrotechnical activities can be distinguished using reflectance data and (2) establish if re-charring (i.e. use of charcoal fuel) can be recognised in the archaeological record through analysis of laboratory-produced re-charred charcoals and charcoals from an experimental iron smelt and traditional bronze casting which utilised charcoal fuel. Reflectance frequency data from assemblages representing burning of charcoal, in this case of iron smelting and bronze casting, indicates temperatures from above the mean value of charcoal production $\left(>475^{\circ} \mathrm{C}\right)$ up to the maximum temperature reached in the subsequent process (i.e. $>475$ to $>1,100^{\circ} \mathrm{C}$ ). In contrast, wildfire charcoals showed a range of values including material with barely measurable reflectance (minimum values from $0.06 \%$ to $0.56 \%$ Ro) to maximum reflectance values varying from $1.65 \%$ Ro (Tilford) to $3.8 \%$ Ro (Zacca). The mean wildfire reflectance indicated temperatures in the range $325-400^{\circ} \mathrm{C}$, which can therefore clearly be distinguished from that of the charcoal burning processes. The laboratory-produced re-charred charcoals take on the reflec-
\end{abstract}

\footnotetext{
L. C. McParland $(\bowtie) \cdot$ M. E. Collinson - A. C. Scott

Department of Earth Sciences, Royal Holloway,

University of London,

Egham,

Surrey TW20 0EX, UK

e-mail: 1.mcparland@es.rhul.ac.uk

G. Campbell

English Heritage, Fort Cumberland,

Fort Cumberland Road, Eastney,

Portsmouth PO4 9LD, UK
}

tance value of the highest temperatures experienced; reflectance values were not constrained by the original temperature of formation. High temperatures are most easily achievable by the burning of charcoal fuel, and hence high reflectance charcoals are likely to represent re-charred charcoal. Therefore, this quantitative reflectance method can be used in archaeology to determine the minimum temperature of formation of charcoals in anthropological processes which involve fire, can indicate the likelihood of use of charcoal or wood as fuel and can distinguish between an assemblage of high temperature anthropogenic charcoals and charcoals formed from natural wildfire.

Keywords Charcoal $\cdot$ Metallurgy $\cdot$ Fuels $\cdot$ Reflectance . Petrography - Wildfire

\section{Introduction}

Analysis of archaeological charcoals has focused on the study of selection of species for fuel and other uses as well as a means of studying of vegetation history and reconstructing contemporary vegetation (Figueiral and Mosbrugger 2000; Marguerie and Hunot 2007). It has also focussed to a lesser extent on radiocarbon dating (Bird 2006). Little data exists on the temperature of formation of ancient charcoals by direct analysis of archaeological material. Temperature analysis of archaeological material can provide primary evidence of the temperature of ancient processes and could allow temperature profiles to be constructed which in turn could help ascertain the origin of the charcoal material, be it as a result of natural processes such as wildfire or through anthropogenic activity. This is also relevant when studying occupation sites dating to the Mesolithic and earlier, where understanding whether concentrations of charcoal are the 
result of wildfire, set fires or derived from hearths is of some importance.

Quantified cell wall reflectance values enable determination of the minimum temperature of formation of charcoal (Jones et al. 1991). The connection between increasing temperature of formation and increasing reflectance value of charcoal from wood has long been recognised (Jones et al. 1991; Scott and Jones 1991, 1994; Scott 2000; Scott and Glasspool 2005, 2007; Braadbaart and Poole 2008). This relationship has also been observed in the reflectance values of ferns and bracket fungi (McParland et al. 2007; Scott and Glasspool 2007). The reflectance/temperature proxy can be applied to charcoals from many contexts including those formed by inclusion in volcanic deposits (Scott and Glasspool 2005; Scott et al. 2008), charcoals formed as a result of natural wildfire both in the present day and through time (Scott and Jones 1994; Scott et al. 2000) and potentially charcoals associated with anthropologic activity. The method needs only small fragments and could be applied on many scales, i.e. to study charcoal inclusions within metallurgical slag (Dillmann and L'Héritier 2007) or charcoals associated with industrial scale activity such as those found at the Iron Age salt workings at Marsal, France (Olivier and Kovacik 2006).

In the past, many processes have relied upon charcoal as a fuel. This is because charcoal is preferable to wood as it has the ability to provide the sustained high temperatures needed in processes such as metallurgy (Henderson 2000). Charcoal has a heat value of 6,500-7,200 kcal $/ \mathrm{kg}$, which is similar to that of bituminous coal (Olson 1991). However, coal could not be utilised in the iron smelting industry prior to the sixteenth century due to its high sulphur content, as no means of removing the sulphur had then been discovered (Gale 1981). Charcoal remained an important fuel even after coal-based iron industries began to flourish in the eighteenth century (Hayman 2008). Charcoal was relatively inexpensive and could often be produced locally, close to the site of industrial activity. Charcoal as a residue of pyrotechnical processes occurs widely in relevant archaeological contexts (for example from Iron Age and Roman deposits associated with iron smelting at Wakerley, Northamptonshire; Jackson et al. 1978). Therefore, analysis of charcoal recovered from the archaeological record can be a useful tool for archaeologists to determine various types of human activity involving the use of fire for example metallurgical processes (Bayley et al. 2001), glass production (Henderson 2000), pottery firing (Livingstone-Smith 2001) and domestic hearths (McDonnell 2001).

However, charcoals also appear in the archaeological record as a result of natural wildfires. This paper aims to (1) determine whether wildfire charcoals and anthropological charcoals from various pyrotechnical activities can be distinguished using reflectance data and (2) establish if re-charring (i.e. use of charcoal fuel) can be recognised in the archaeological record through analysis of laboratoryproduced re-charred charcoals and charcoals from an experimental iron smelt and traditional bronze casting which utilised charcoal fuel. Charcoal assemblages were also obtained from experimental charcoal production in a traditional earth clamp and from four natural wildfires in the UK and the USA for comparison. Reflectance frequency distributions are used to compare the charcoal assemblages and determine if charcoals from anthropogenic activity can be distinguished from those produced by natural wildfires.

\section{Laboratory re-charring experiments}

Underlying rationale

Laboratory re-charring experiments were undertaken to simulate initial production of charcoal and then subsequent use as a fuel in a high temperature industrial process. Quercus (oak) was selected for the re-charring experiments as it was commonly used, in the UK, in high temperature industrial processes such as iron smelting because of its ability to provide high temperature sustained heat (Howkins 1994). Figures concerning temperatures and durations of processes have been derived primarily from unpublished experimental work undertaken at the Weald and Downland Open Air Museum (charcoal production) and with the Wealden Iron Research Group (iron smelting). In the process of charcoal production, initially the wood is converted to charcoal by heating in the absence of air. We selected three initial temperatures for conversion from wood to charcoal, 300,500 and $800^{\circ} \mathrm{C}$, to cover the range of likely temperatures of formation during anthropogenic charcoal production as a fuel in a traditional earth clamp. The wood was subjected to these temperatures for a duration of $5 \mathrm{~h}$ to simulate the time needed to produce a yield of charcoal from a typical size traditional earth clamp or steel kiln. The charcoal produced was then subsequently re-charred for $5 \mathrm{~h}$ at $800^{\circ} \mathrm{C}$ to simulate a range of relatively high temperature processes such as pottery firing (Livingstone-Smith 2001) and at $1,100^{\circ} \mathrm{C}$ for $5 \mathrm{~h}$ to simulate very high temperature processes such as the smelting of iron (Turner 1956; Wealden Iron Research Group, personal communication).

Experimental methodology

The Quercus (oak) was obtained from Bagley Wood sawmill in Oxford, UK, and had been left to season outside for 8 months prior to bringing to the laboratory where it was milled into $20-\mathrm{mm}$ diameter by $75-\mathrm{mm}$ length cylinders of wood (bark excluded). The experimental 
charring method and equipment used follows that of Scott and Glasspool $(2005,2007)$ and McParland et al. (2007). Pieces of the oak were pre-milled to fit steel containers, which were specially designed to exclude oxygen from entering the experiment, thus allowing pyrolysis and preventing complete combustion, but also permitting the release of volatiles from the heated wood. Four milled pieces were used in each run of the experiment each in separate tubes, one to be used as a control specimen and three to be re-charred at a higher temperature. Each piece was weighed and this weight recorded. The wood was placed directly in the tubes (i.e. not wrapped in tin foil first). The tubes were then placed in a preheated Carbolite temperature-controlled oven (LHT 6/60) or furnace (CWF 1100 ) set to the initial charring temperature of either 300,500 or $800^{\circ} \mathrm{C}$. Samples were charred at this temperature for $5 \mathrm{~h}$. The charring time was measured having allowed $40 \mathrm{~min}$ for the samples to reach the desired temperature (based on previous work by McParland et al. 2007). Oven temperatures were recorded using a Pico TC-08 thermocouple. After $5 \mathrm{~h}$, the samples were removed and left in the steel containers to cool (approximately $20 \mathrm{~min}$ ) before being weighed again to determine weight loss. Three pieces from each of the initial starting temperatures were replaced in the steel containers, placed in the preheated furnace at 800 or $1,100^{\circ} \mathrm{C}$ and charred for a further $5 \mathrm{~h}$ before being removed, cooled and weighed. For comparison with the charcoals generated by recharring $(5+5 \mathrm{~h})$, wood was charred for a single period of $5 \mathrm{~h}$ at $300,500,800$ and $1,100^{\circ} \mathrm{C}$ and a single period of $10 \mathrm{~h}$ at 800 and $1,100^{\circ} \mathrm{C}$. A set of charcoals were also produced with 1-h and $24-\mathrm{h}$ charring at temperatures $300-1,100^{\circ} \mathrm{C}$. In total, samples would incur $1 \mathrm{~h}$ additional time within the steel containers $(40 \mathrm{~min}$ for the sample to get to temperature and $20 \mathrm{~min}$ cooling time within the steel container once removed from the oven). A reference collection of all charcoals is deposited at English Heritage, Fort Cumberland.

\section{Field experiments: charcoal production in a traditional earth clamp}

All process-specific material (charcoal production in a traditional earth clamp, bronze casting, iron smelting) was obtained from modern day field experiments, which aim to replicate the process as it occurred in the past; this was so that the origin of the material could be infallibly identified and the conditions of formation observed first hand.

The charcoal production experiment was conducted at the Weald and Downland Open Air Museum, Chichester, UK. The experiment aimed to produce charcoal fuel from seasoned Corylus, Acer and Fraxinus wood using a traditional earth clamp (Howkins 1994; Hollingdale et al.
1999). A central peg was inserted into the centre of the platform where charcoal burns had previously occurred. The clamp was then built up by laying lengths of wood against the peg so that as many of the timbers as possible were touching such that the structure became selfsupporting. Thicker lengths were used to build up the centre saving the thinner lengths for the outside. The peg was removed, once the structure was stable, and the clamp continued to be built outwards until the radius of the clamp was equal to the length of the individual timbers. As the layers were built up, the timbers were laid at an angle avoiding leaving any large gaps. Once complete, the centre of the clamp, where the peg had been, was filled with kindling. The whole clamp was then covered with hay and dampened down with water before being covered with sieved soil.

The clamp was then lit and, once flames were seen coming out of the top, a bridge was built over the flu with green branches and leaves and then covered with fresh turf. When conversion to charcoal was complete, the smoke turned from cloudy to clear. It was ensured that the clamp was closed before the smoke turned blue (which would indicate that the charcoal was burning). For a clamp of this size, the duration between lighting the clamp and closing the clamp was approximately $5 \mathrm{~h}$. The clamp was then closed down by poking holes in the earth wall with the peg and pouring water into these holes in several places across the clamp. After opening, ten individual charcoal fragments were taken from random positions within the clamp and each was subsequently crushed in the laboratory.

\section{Field experiments: experimental metalworking}

Dr Tim Young of GeoArch kindly donated material from a traditional iron smelting experiment held at the Severn Valley Country Park, Shropshire in July 2007. The smelt took place using a traditional bloomery furnace built for the experiment. The furnace was charged with charcoal and replenished when needed. Once lit, it took approximately $1 \mathrm{~h} 30 \mathrm{~min}$ for the ore to begin charging; the total smelt time was $4 \mathrm{~h}$ followed by $2 \mathrm{~h}$ of smithing of the bloom once the top of the furnace had been removed. The charcoal material was then recovered from the residue within the furnace.

Mr Neil Burridge of Bronze Age Craft, who specialises in reproducing Bronze Age artefacts using authentic materials and methods, kindly donated the bronze casting material. The charcoal was collected from the residue of a bronze casting experiment; typically oak charcoal was used. The charcoal was heated for approximately $30 \mathrm{~min}$ and the extreme maximum temperature recorded within the oven was $1,160^{\circ} \mathrm{C}(\mathrm{N}$. Burridge, personal communication). 


\section{Natural wildfire assemblages}

Charcoals from four modern wildfires were selected for inclusion in this study. In each case, the sample was divided randomly, a sub-sample was crushed and sieved to obtain the $1-2-\mathrm{mm}$ fraction and then embedded. The following four wildfires were studied:

Tilford: Frensham Common Country Park, near Tilford, Surrey, Southeast England in 1996. Rapidly spreading surface fire on heather heathland with birch and pine (see Scott et al. 2000 for details of vegetation and charcoal deposits at Tilford). Two samples studied representing two sampling locations T1 and T15.

Thursley: Thursley Common, Surrey, Southeast England in 2006. Wildfire on heather heathland (dominated by Erica and Calluna with lesser amounts of gorse (Ulex) and scattered young trees of birch (Betula) and pine (Pinus)). Sample number THU 010801.

Hayman: near Denver, Colorado, USA in 2002. Wildfire in Ponderosa Pine Forest. Sample from charred litter of predominantly Pinus ponderosa. Material collected with Deborah Martin (USGS). See Graham 2003 for details of the Hayman fire. Two samples studied representing two sampling locations $5 / 1$ and $6 / 1$.

Zacca: near Santa Barbara, California, USA in 2007. Wildfire in chaparral vegetation (see Keeley 2006 for details of central Californian fire regimes). Material collected with Jon Keeley (USGS).

\section{Analytical methodology}

Visual analysis

The laboratory experimental material was assessed for charcoalification (altered completely from wood to charcoal by heating in the absence of excess oxygen) using criteria outlined by Scott and Jones (1991) and used by McParland et al. (2007). These criteria include 3D preservation, black colour and silky sheen, brittle behaviour and a black streak left on hands and paper. The brittle nature of the laboratoryproduced charcoal was categorised according to the result of manual pressure upon the sample - 'not brittle' (did not break with pressure), 'slightly brittle' (broke with strong pressure), 'quite brittle' (broke easily with pressure), 'very brittle' (broke with minimal pressure) and 'extremely brittle' (broke on contact).

\section{Reflectance microscopy}

Thick transverse sections of each of the milled pieces of the laboratory-charred Quercus, and crushed samples of field experimental and wildfire charcoals, were embedded in polyester resin and polished (Jones et al. 1991). The polished blocks were studied (using standard techniques for coal petrography) under the Nikon microphot microscope attached to the Leica QWin image analysis software (Leica Image systems Ltd., 1997). Random reflectance was measured under Cargill immersion oil (refractive index of 1.518 at $23^{\circ} \mathrm{C}$ ) using the $\times 40$ objective lens, using 546-nm light. The instrument was calibrated against five standards: Spinel (Ro 0.393), YAG (Ro 0.929), GGG (Ro 1.7486), cubic zirconium (Ro 3.188) and silicon carbide (Ro 7.506). One hundred points were measured randomly from each sample (this was repeated three times with three separate samples for the re-charred material). An initial survey found there was no obvious variation in mean random reflectance between various wood cells, therefore all cell types were included in the analysis; no difference has been seen in any of previous published work by the authors (Jones et al. 1991; Scott and Jones 1991; Scott and Glasspool 2007; McParland et al. 2007) nor is there documentation in the literature of a difference in similar experiments (Guo and Bustin 1998; Bustin and Guo 1999; Braadbaart and Poole 2008).

\section{Temperature-reflectance relationship}

A relationship between increasing temperature and duration of charring and increasing reflectance value is known and applies to both softwoods and hardwoods (Jones et al. 1991; Scott and Jones 1991, 1994; Scott 2000; Scott and Glasspool 2005, 2007; McParland et al. 2007; Braadbaart and Poole 2008). A calibration curve is generated by charring at known temperatures and durations and plotting the resulting reflectance values. The formation temperature of samples with unknown charring temperature can be obtained from the curve using the measured reflectance value. The durations of charring for many processes could vary by several hours; however, durations are unlikely to be less than $1 \mathrm{~h}$ and duration of charring has little effect on reflectance after $24 \mathrm{~h}$. Hammes et al. (2006) considered charring to be complete in $5 \mathrm{~h}$. In terms of reflectance, samples exposed to temperatures $<450^{\circ} \mathrm{C}$ will show maximum reflectance after $1 \mathrm{~h}$ whereas at higher temperatures reflectance will continue to rise with time after $1 \mathrm{~h}$ but at a slower rate (Scott and Glasspool 2007). In this study, therefore, temperatures were inferred from both a 1-h and 24-h calibration curve (Fig. 4). The results are expressed as a range of temperature, e.g. a reflectance of $5 \%$ Ro would need to be charred at $900^{\circ} \mathrm{C}$ for $1 \mathrm{~h}$ or $800^{\circ} \mathrm{C}$ for $24 \mathrm{~h}$ giving a range of $800-900^{\circ} \mathrm{C}$.

Scanning electron microscopy

Sections of each milled sample from the laboratory charring experiments were fractured using a fresh sharp single-edged 
razor blade to obtain transverse, tangential longitudinal and radial longitudinal sections. These were then mounted on aluminium stubs using double-sided sticky tabs. The samples were examined uncoated using a Hitachi S-3000 scanning electron microscope at $25 \mathrm{kV}$ using the backscatter detector.

\section{Results}

Laboratory-charred charcoals and re-charring experiments

Visual analysis, brittle behaviour, breakage and shrinkage Visual criteria (3D preservation, black colour, silky sheen, brittle behaviour and black streak) indicating formation of charcoal were recognised for all samples generated $>300^{\circ} \mathrm{C}$ (Table 1). A silky sheen was present in all 5-h samples becoming more pronounced by re-charring at 800 and $1,100^{\circ} \mathrm{C}$. Brittleness increased with increasing temperature of formation becoming extremely brittle at $1,100^{\circ} \mathrm{C}$ for $10 \mathrm{~h}$. Re-charring of all the initial chars at 800 and $1,100^{\circ} \mathrm{C}$ had the effect of making the sample more brittle. The 300 and $500^{\circ} \mathrm{C}$ samples remained intact but then broke apart during re-charring at both 800 and $1,100^{\circ} \mathrm{C}$. The 800 and $1,100^{\circ} \mathrm{C}$ single charring duration samples broke during the charring. In many cases, the charcoals fractured and exhibited differential shrinkage in the transverse plane (Fig. 1). In all cases, the samples had decreased in size from dimensions as wood, and then further decreased in size after re-charring, however, this was not quantified in this study due to its limited use when original dimensions of charcoals from archaeological contexts would not be known (Braadbaart and Poole 2008).

Weight reduction Increasing temperature of formation led to increasing weight loss (Fig. 2). In the conversion of wood to charcoal by charring for $5 \mathrm{~h}$, weight was reduced at $300^{\circ} \mathrm{C}$ by average $48 \%$, at $500^{\circ} \mathrm{C} 78 \%$ and at $800^{\circ} \mathrm{C} 84 \%$. Recharring at a higher temperature increased weight loss. After re-charring for a subsequent $5 \mathrm{~h}$ at $800^{\circ} \mathrm{C}$, the $300^{\circ} \mathrm{C}$ samples were reduced by a further $49 \%$ in total having lost $76 \%$ of their original 'wood' weight, the $500^{\circ} \mathrm{C}$ samples were reduced by a further $16 \%(82 \%$ total loss $)$ and the $800^{\circ} \mathrm{C}$ samples were reduced a further $1 \%(84 \%$ total loss $)$. After re-charring for a subsequent $5 \mathrm{~h}$ at $1,100^{\circ} \mathrm{C}$, the $300^{\circ} \mathrm{C}$ samples were reduced by a further $65 \%$ ( $83 \%$ total loss), the $500^{\circ} \mathrm{C}$ samples were reduced by a further $22 \%$ ( $83 \%$ total loss) and the $800^{\circ} \mathrm{C}$ samples were reduced by a further $25 \%$ ( $87 \%$ total loss). In comparison, the $10-\mathrm{h}$ single char at $800^{\circ} \mathrm{C}$ had an $82 \%$ total weight loss and the $1,100^{\circ} \mathrm{C}$ for $10 \mathrm{~h}$ a $93 \%$ total weight loss.

Mean random reflectance All samples showed measurable reflectance in polished blocks under oil (Table 2, Fig. 3). In the initial single 5-h chars, increasing temperature of formation led to increasing reflectance (Figs. 3 and 4); this was comparable to the expected trend shown for 300$1,100^{\circ} \mathrm{C}$ for $1 \mathrm{~h}$ (Fig. 4), which itself is comparable to previous work on woods (Jones et al. 1991; Guo and Bustin 1998; Bustin and Guo 1999; McParland et al. 2007; Scott and Glasspool 2007; Braadbaart and Poole 2008). The samples charred at 300,500 and $800^{\circ} \mathrm{C}$ for $5 \mathrm{~h}$, which were re-charred for a further $5 \mathrm{~h}$ at $800^{\circ} \mathrm{C}$, all took on the reflectance value of those charred for 5 or $10 \mathrm{~h}$ at $800^{\circ} \mathrm{C}$ (Fig. 4). The same response was found in samples that had been re-charred for a further $5 \mathrm{~h}$ at $1,100^{\circ} \mathrm{C}$ (Fig. 4).

Scanning electron microscopy There was no visible effect of re-charring upon cellular structure of the woods when viewed under scanning electron microscopy (SEM). The structure of the rays remained intact. Homogenisation (loss of layering) of the cell walls was seen in all samples that had reached temperatures in excess of $325^{\circ} \mathrm{C}$ either initially

Table 1 Visual analysis of Quercus wood after heating at various temperatures

\begin{tabular}{|c|c|c|c|c|c|}
\hline Temperature & Intact? & Colour of specimen & Colour of streak & Silky sheen? & Brittleness? \\
\hline $300^{\circ} \mathrm{C} 5 \mathrm{~h}$ & Yes & Dark grey & Black & Slight & Not brittle \\
\hline $500^{\circ} \mathrm{C} 5 \mathrm{~h}$ & Yes & Dark grey & Black & Slight & Slightly brittle \\
\hline $800^{\circ} \mathrm{C} 5 \mathrm{~h}$ & No & Black & Black & Yes & Quite brittle \\
\hline $300^{\circ} \mathrm{C} 5 \mathrm{~h}+800^{\circ} \mathrm{C} 5 \mathrm{~h}$ & No & Black & Black & Yes & Quite brittle \\
\hline $500^{\circ} \mathrm{C} 5 \mathrm{~h}+800^{\circ} \mathrm{C} 5 \mathrm{~h}$ & No & Black & Black & Yes & Quite brittle \\
\hline $800^{\circ} \mathrm{C} 5 \mathrm{~h}+800^{\circ} \mathrm{C} 5 \mathrm{~h}$ & No & Black & Black & Very & Quite brittle \\
\hline $300^{\circ} \mathrm{C} 5 \mathrm{~h}+1,100^{\circ} \mathrm{C} 5 \mathrm{~h}$ & No & Black & Black & Very & Very brittle \\
\hline $500^{\circ} \mathrm{C} 5 \mathrm{~h}+1,100^{\circ} \mathrm{C} 5 \mathrm{~h}$ & No & Black & Black & Very & Very brittle \\
\hline $800^{\circ} \mathrm{C} 5 \mathrm{~h}+1,100^{\circ} \mathrm{C} 5 \mathrm{~h}$ & No & Black & Black & Very & Very brittle \\
\hline $800^{\circ} \mathrm{C} 10 \mathrm{~h}$ & No & Black & Black & Very & Very brittle \\
\hline $1,100^{\circ} \mathrm{C} 10 \mathrm{~h}$ & No & Black & Black & Very & Extremely brittle \\
\hline
\end{tabular}


Fig. 1 The effect of charring upon the physical appearance of Quercus charcoal $(\mathbf{a}, \mathbf{b}, \mathbf{d})$ and re-charring (c) to illustrate shrinkage and fracturing along transverse planes in high temperature and re-charred specimens. a-b Complete specimens, $\mathbf{c}-\mathbf{d}$ fragments of specimens, which broke after charring. Scale bars $=1 \mathrm{~cm}$

\section{a uncharred wood}

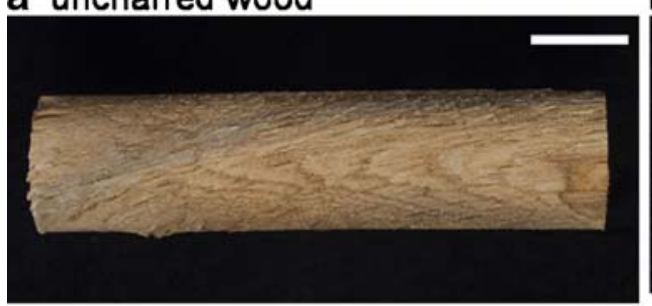

c $500^{\circ} \mathrm{C} / 5 \mathrm{hrs}+1100^{\circ} \mathrm{C} / 5 \mathrm{hrs}$

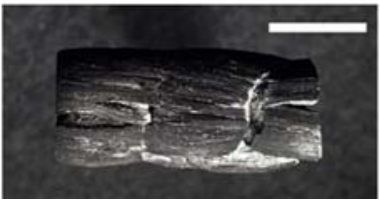

b $500^{\circ} \mathrm{C} / 5 \mathrm{hrs}$

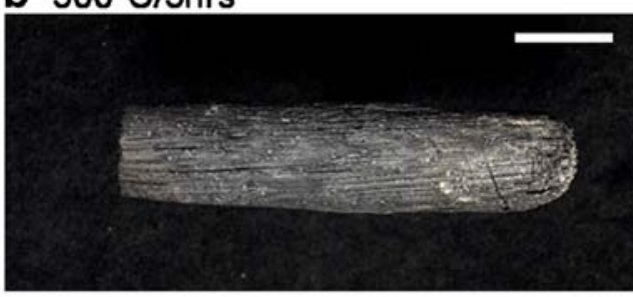

d $1100^{\circ} \mathrm{C} / 5 \mathrm{hrs}$

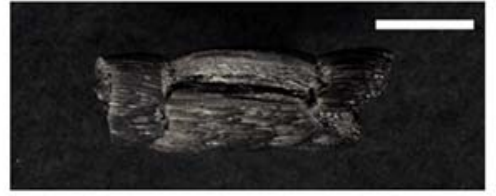

or by re-charring at a higher temperature. All samples remained completely comparable in the preservation of their cellular structure regardless of whether the sample had been re-charred or not (Fig. 5).

Charcoals from traditional clamp production (Fig. 6)

Visually, the samples produced by the traditional earth clamp field experiment had the criteria of charcoal as outlined by Scott and Jones (1991) and used by McParland et al. (2007) consisting of 3D preservation, black colour and silky sheen, brittle behaviour and a black streak left on hands and paper. Physically, the samples felt relatively lighter in weight once converted from wood to charcoal and had visibly shrunk, although this was not quantified. The above behaviour and characteristics were observed in all wood species used in the clamp.

The traditional charcoal clamp experiment gave reflectance values that plotted in a normal distribution histogram with a mean of $1.41 \%$ Ro (Fig. 6, Table 2) indicating a

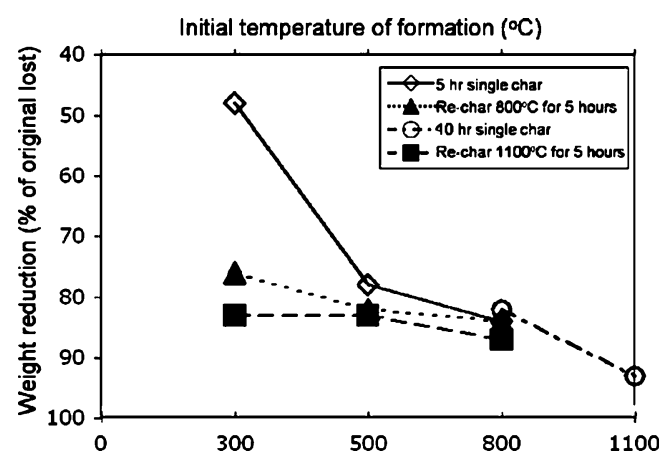

Fig. 2 Percentage weight reduction under different experimental temperatures for Quercus wood showing increasing weight loss with increasing temperature of formation (open symbols indicate a single period of charring at the temperature indicated on the $x$ axis, closed symbols indicate re-charring of charcoal at the temperature indicated by the key) temperature of $400-475^{\circ} \mathrm{C}$. The minimum value was $0.79 \%$ Ro and the maximum $2.33 \%$ Ro, indicating the extreme range of temperature of formation to be $375-590^{\circ} \mathrm{C}$.

Charcoals from iron smelting and bronze casting (Fig. 6)

The samples produced by the iron smelting and the bronze casting field experiment had the criteria of charcoal as outlined by Scott and Jones (1991) and used by McParland et al. (2007) consisting of 3D preservation, black colour and silky sheen, brittle behaviour and a black streak left on hands and paper. Charcoal residue from both experiments also felt relatively lighter in weight. As the starting charcoal was so variable in size, shrinkage was not described.

In the iron smelting and bronze casting experiments, minimum reflectance values recorded were above $2.51 \%$ Ro (Table 2, Fig. 6). There is a wide spread of values with low frequency peaks (Fig. 6). The iron smelting gave a mean of $4.96 \%$ Ro indicating temperatures of approximately $800^{\circ} \mathrm{C}$, with a maximum of $6.81 \%$ Ro and a minimum of $3.09 \%$ Ro giving an extreme range of 550 to $>1,100^{\circ} \mathrm{C}$. Bronze casting yielded very similar results with a mean of $5.07 \%$ Ro indicating temperatures of approximately $800^{\circ} \mathrm{C}$ with a maximum of $7.01 \%$ Ro and a minimum of $2.52 \%$ Ro giving an extreme range of 475 to $>1,100^{\circ} \mathrm{C}$.

\section{Charcoals from natural wildfires (Fig. 6)}

All the natural wildfire samples showed a range of values including material with barely measurable reflectance (minimum values from $0.06 \%$ to $0.56 \%$ Ro). Maximum reflectance values varied in different fires from $1.65 \%$ Ro (Tilford) to $3.8 \%$ Ro (Zacca). The histograms showed a non-normal distribution. In the case of the Tilford (Frensham) and Thursley fires, the mean values ranged from $0.71 \%$ to $0.84 \%$ Ro indicating temperatures of $325-$ $400^{\circ} \mathrm{C}$. The Hayman charcoals gave very similar results to Tilford and Thursley with non-normal distribution of 
Table 2 Reflectance data of the metallurgy, clamp and wildfire charcoals

\begin{tabular}{llllllllll}
\hline & Hayman 5/1 & Hayman 6/1 & Thursley & Tilford T1 & Tilford T15 & Zacca & Clamp & Iron smelt & Copper working \\
\hline Mean & 0.66 & 0.68 & 0.71 & 0.84 & 0.82 & 2.36 & 1.41 & 4.96 & 5.07 \\
Median & 0.64 & 0.79 & 0.71 & 0.85 & 0.79 & 2.74 & 1.41 & 5.02 & 5.36 \\
Maximum & 1.77 & 1.85 & 1.85 & 1.79 & 1.65 & 3.80 & 2.33 & 6.81 & 7.01 \\
Minimum & 0.27 & 0.20 & 0.30 & 0.15 & 0.06 & 0.56 & 0.79 & 3.09 & 2.52 \\
Standard deviation & 0.36 & 0.45 & 0.28 & 0.38 & 0.32 & 0.84 & 0.35 & 0.89 & 0.97 \\
\hline
\end{tabular}

values, and means of $0.66 \%$ Ro and $0.68 \%$ Ro for the two samples, indicating charring temperatures around 320 $375^{\circ} \mathrm{C}$. The minimum (0.06-0.3\%Ro) and maximum $(1.65-1.85 \%$ Ro) reflectance values obtained in the Hayman, Thursley and Tilford fires were very similar and indicate an extreme temperature range of $300-520^{\circ} \mathrm{C}$. Reflectance distributions from the Tilford, Thursley and Hayman fires were skewed towards lower values. The Zacca wildfire sample gave a very different result with lower peak heights and a very wide spread of values spanning $0.56 \%$ to $3.8 \%$ Ro with the spread skewed to higher values. The mean of $2.36 \%$ Ro indicates a temperature of $475-600^{\circ} \mathrm{C}$; the extreme range indicated temperatures between 300 and $700^{\circ} \mathrm{C}$.
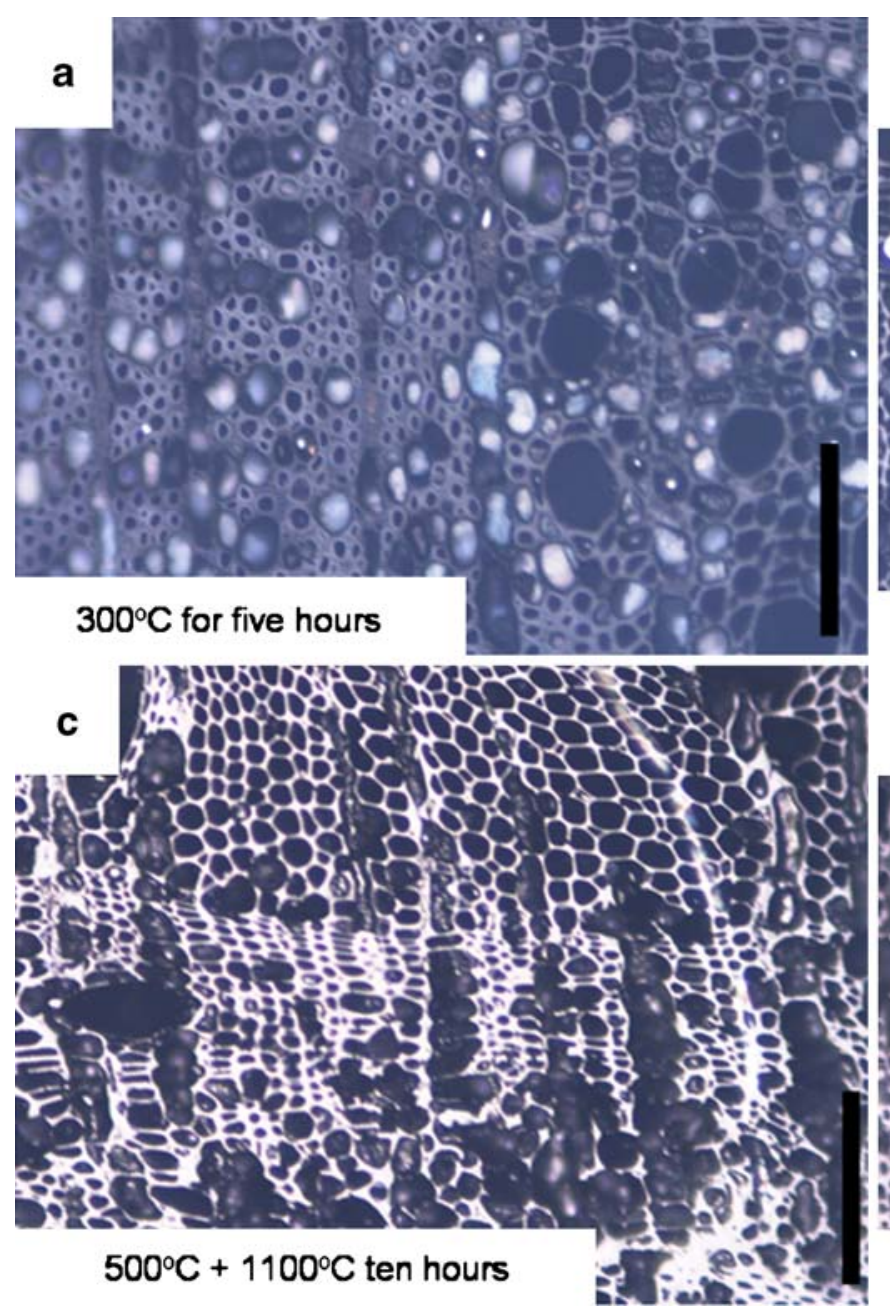

Fig. 3 Reflectance images, from polished blocks under oil, to show increasing reflectance with increasing temperature of formation $(\mathbf{a}-\mathbf{d})$ and how re-charring causes the samples to take on the reflectance of
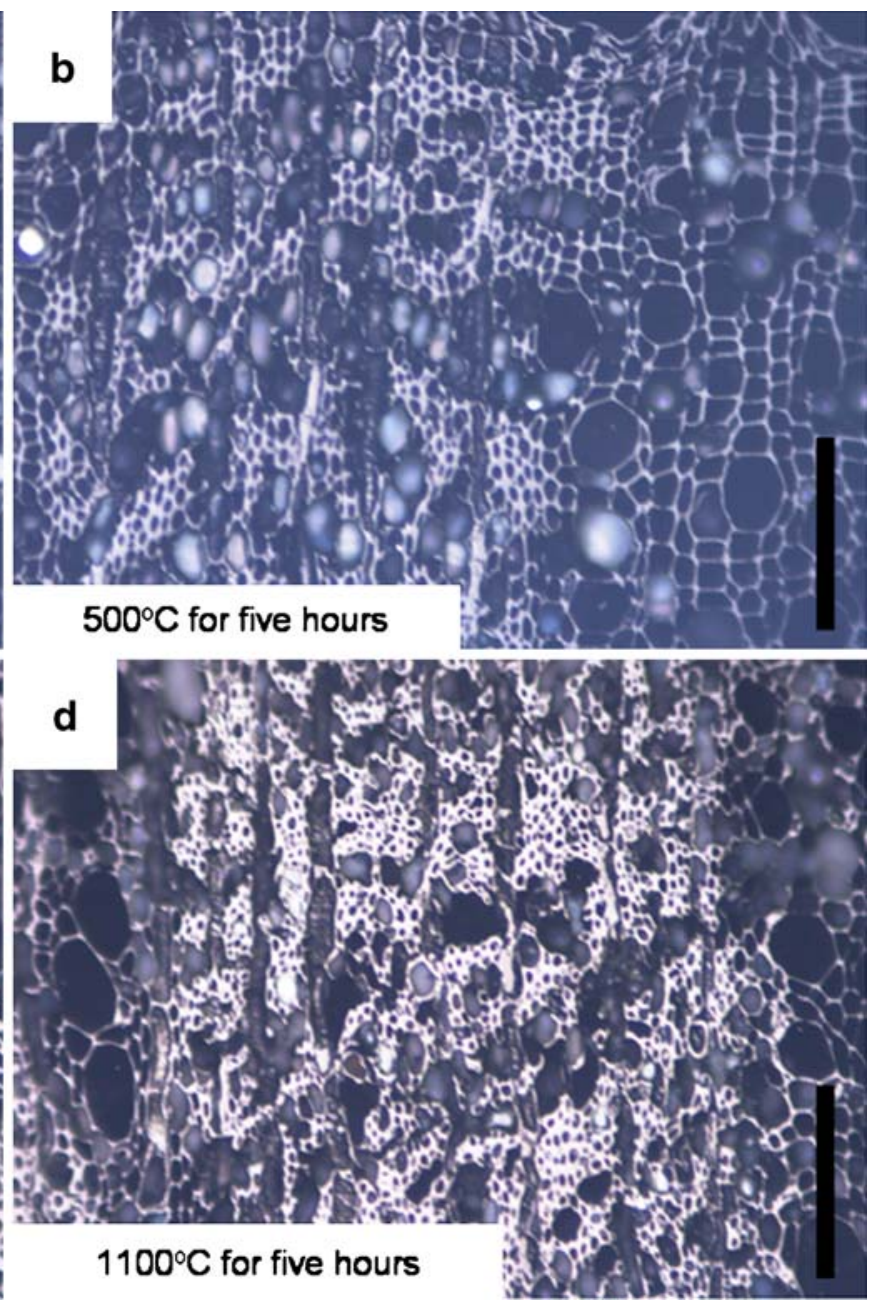

the highest temperature reached (c). Note in (a) that wall layers have not homogenised. Images obtained in color and not modified after acquisition. Scale bars are $100 \mu \mathrm{m}$ 


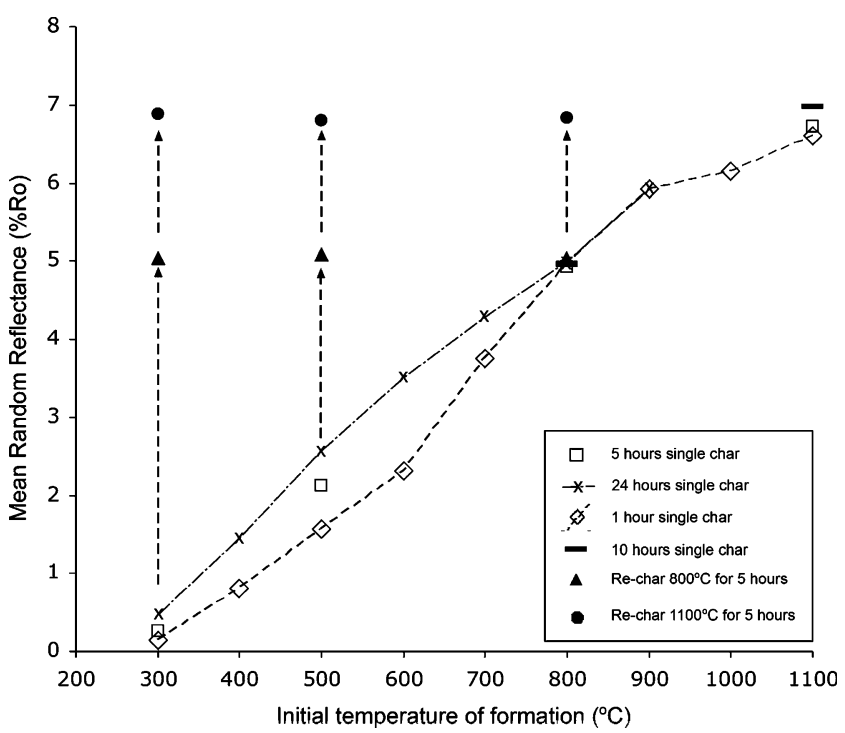

Fig. 4 Mean random reflectance under oil of charcoals produced at different temperatures, showing how re-charring causes the sample to take on the reflectance of the highest temperature reached. Closed symbols indicate those specimens which have been re-charred at a higher temperature for $5 \mathrm{~h}$ after the initial charring for $5 \mathrm{~h}$ at temperature indicated by the $x$ axis (triangles $=$ further $800^{\circ} \mathrm{C}$ for $5 \mathrm{~h}$, circles $=$ further $1,100^{\circ} \mathrm{C}$ for $5 \mathrm{~h}$ ). Arrows indicate the change in reflectance with recharring. Error bars fall within the symbols $\left(800^{\circ} \mathrm{C} / 1 \mathrm{~h}, 800^{\circ} \mathrm{C} / 24 \mathrm{~h}\right.$, $800^{\circ} \mathrm{C} / 5 \mathrm{~h}, 800^{\circ} \mathrm{C} / 10 \mathrm{~h}$ and $800^{\circ} \mathrm{C} / 5 \mathrm{~h}+800^{\circ} \mathrm{C} / 5 \mathrm{~h}$ points overlap)

\section{Discussion}

Weight reduction and shrinkage in charcoals

The weight reduction in charcoal during heating has been widely recognised (Bustin and Guo 1999; Czimczik et al. 2002; Gonzales-Vila et al. 2001; Hammes et al. 2006; McParland et al. 2007). In our laboratory study, the higher the temperature of formation or the longer the duration of charring, the more weight was lost from the sample (Fig. 2). This is due to the release of moisture and volatiles from the wood during heating. Loss of water and cellulose contents in wood occurs at low temperatures. At temperatures of $\sim 350^{\circ} \mathrm{C}$, carbon monoxide and methane are released; at $500^{\circ} \mathrm{C}$, cellulose begins to break down into volatiles (Bustin and Guo 1999). Therefore, both duration and temperature of heating are important in the loss of weight from wood. Subsequent re-charring at a higher temperature resulted in total weight loss similar to that of samples charred continuously at the higher temperature. The samples that had been re-charred at $1,100^{\circ} \mathrm{C}$ for $5+5 \mathrm{~h}$ did not lose as much weight as those charred continuously at $1,100^{\circ} \mathrm{C}$ for $10 \mathrm{~h}$. There was also visible increasing shrinkage with increasing temperature of formation of laboratory charcoals (Fig. 1) in both the single charred (Fig. 1d) and re-charred (Fig. 1c) samples.
However, application of these parameters to determine relative temperatures reached during formation of charcoals of unknown provenance is near impossible. The original dimensions would not be known in an archaeological context and charcoals would have to be of comparable size and cell structure, completely dry and lacking any foreign material (such as silt or iron deposition) which might influence their weight. However, if they could be recognised as such in the archaeological record, relatively lighter weight more shrunken charcoals would indicate higher temperature of formation.

Recognising the use of charcoal as a fuel (i.e. re-charring of charcoal)

Both conversion of a specimen of wood to charcoal and subsequent re-charring of this specimen yield recognisable charcoals (Figs. 1b-d, 3 and 5). Homogenisation of the cell wall layers occurred in all samples subjected to temperatures above $325^{\circ} \mathrm{C}$ either initially or during subsequent recharring. The structure of the wood was preserved in charcoal to a degree that should allow the formal identification of species even at temperatures of $1,100^{\circ} \mathrm{C}$. Re-charring did not alter the cellular structure of wood anymore than subjecting wood to a single period of charring (Fig. 5). Therefore, at the tissue level studied here (Fig. 5), there are no structural changes in woods that could be used in an unknown sample to indicate either re-charring of charcoal during use as a fuel or the use of high temperature processes (at least up to $1,100^{\circ} \mathrm{C}$ ).

It would not be possible to determine that a sample had been re-charred using mean random reflectance because the specimen would take on the reflectance of the subsequent higher temperature char and this is not distinguishable from that resulting from a single period of charring at the higher temperature (Fig. 4). However, reflectance can be used to demonstrate that samples have at some stage been subjected to high temperatures, and these temperatures can be quantified, because reflectance was not constrained by the original temperature of formation but is overridden by subsequent charring at higher temperatures (Fig. 4).

The maximum reflectance value from any of the wildfire charcoals studied here was 3.8\%Ro (Fig. 6 Zacca fire) and all the wildfire assemblages range down to very low values (0.06-0.56\%Ro, Table 2). In stark contrast, assemblages representing the use of charcoal as a fuel (Fig. 6 iron smelting, bronze casting) have very few reflectance values below $4.0 \%$ Ro, and none below $2.52 \%$ Ro, but instead show a wide spread of higher values ranging up to $7.01 \%$ Ro. Laboratory charring experiments show that values of $6.0 \%$ Ro indicate temperatures of formation $>1,000^{\circ} \mathrm{C}$ and $6.5 \%$ Ro $>1,100^{\circ} \mathrm{C}$ (Fig. 4). Therefore, a combination of some very high reflectance values with a spread of overall 


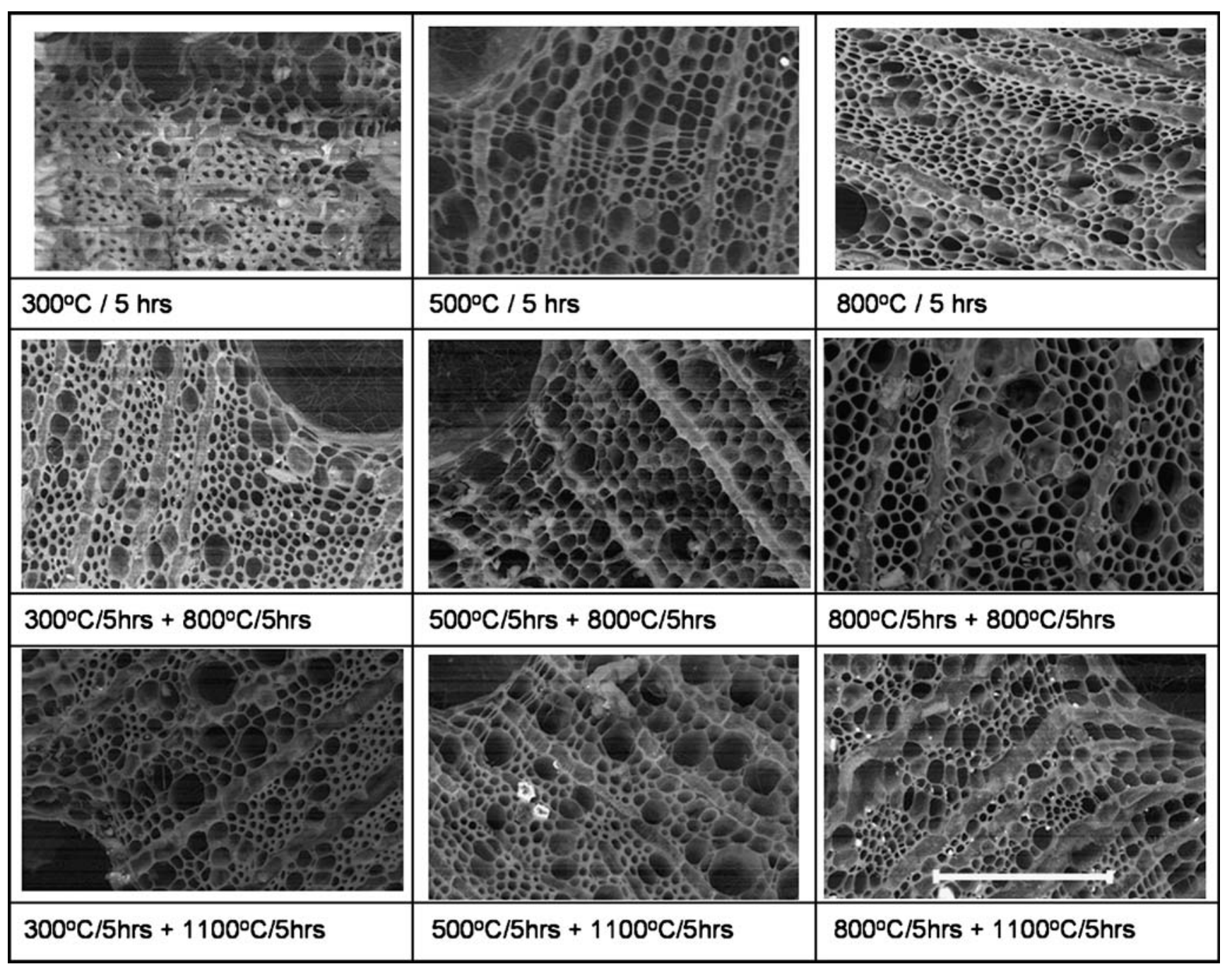

Fig. 5 SEM images to show the retention of the anatomical structure in Quercus after initial charring and subsequent re-charring at 800 and $1,100^{\circ} \mathrm{C}$. Note in $300^{\circ} \mathrm{C} / 5 \mathrm{hrs}$ cell wall layers have not homogenised (scale bar in $800^{\circ} \mathrm{C} / 5+1100^{\circ} \mathrm{C} / 5$ represents $100 \mu \mathrm{m}$ applicable to all images in this figure)

have distributions skewed towards low values and overall low reflectance. The mean of these wildfires reflectance is $0.90 \%$ Ro, which is significantly lower than the mean for charcoal production (1.41\%Ro; Fig. 6). All these reflectance distributions (maximum 2.33\%Ro for the clamp and 1.85 for the wildfires) show no overlap with those from the metallurgy charcoals (iron smelting and bronze casting, minimum $2.52 \%$ Ro) where the mean random reflectance is also much higher $(5.01 \% \mathrm{Ro})$ indicative of high temperature processes. The Zacca fire shows higher reflectance values than the other wildfires and some of the higher values overlap with lower values from the metallurgy charcoals (Fig. 6). This is perhaps due to the vegetation type inducing hotter fires, which can have temperatures as high as $700^{\circ} \mathrm{C}$ (Rundel 1983). However, the overall Zacca fire assemblage is readily recognised as a wildfire assemblage as it includes a spread of low reflectance
Figure 6 shows the signatures of reflectance distribution that characterise different charcoal assemblages. Three of the wildfires (five samples from Tilford, Thursley and Hayman) 


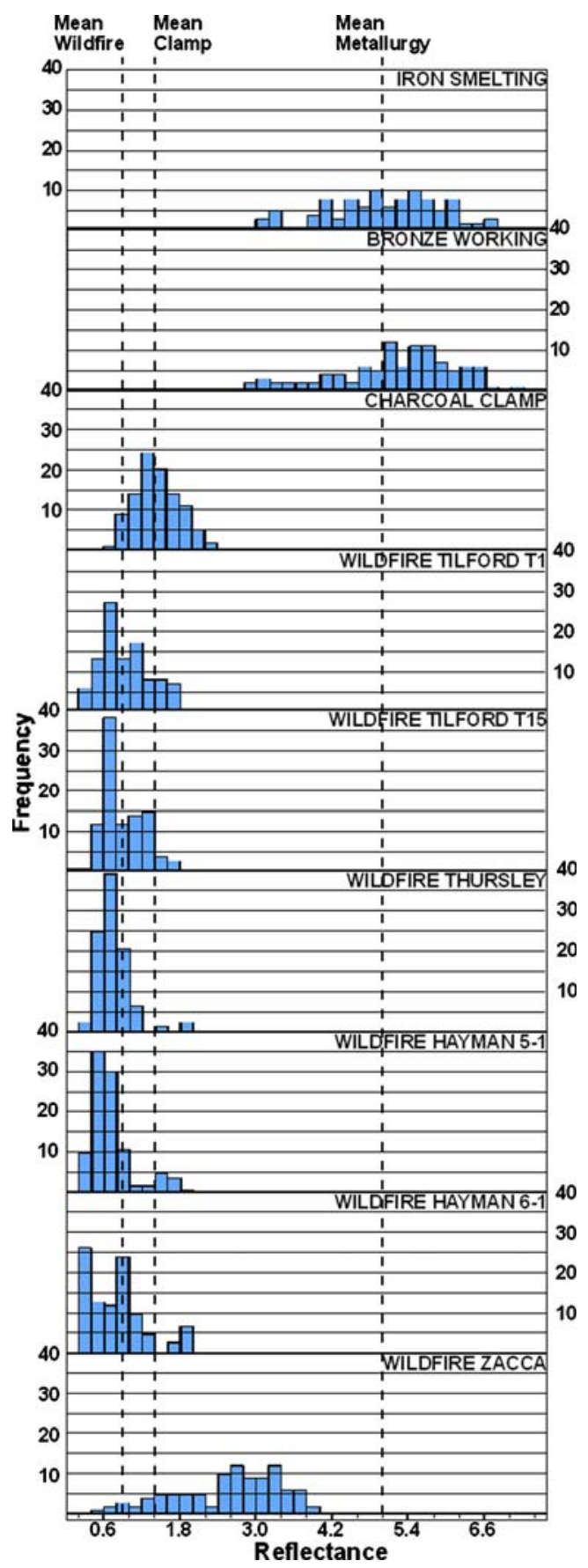

Fig. 6 Frequency histograms to show the distribution of reflectance values for the nine charcoal assemblages (metallurgy, traditional charcoal production clamp and natural wildfires) measured in polished blocks under oil. The mean values for metallurgy, charcoal production and natural wildfire are plotted to highlight the differences, especially evident for the metallurgy samples

values down to $0.56 \%$ Ro (Fig. 6). This minimum reflectance is also below the minimum of the charcoal production clamp assemblage $(0.79 \%$ Ro; Fig. 6 and Table 2$)$ so the Zacca wildfire assemblage could not be confused with an assemblage produced by the re-charring of charcoal.
Reflectance distributions can therefore be used to distinguish between wildfire and high temperature archaeological processes where charcoal has been produced and then recharred in a process such as metallurgy. Whether or not low temperature anthropologic processes such as charcoal production (or others such as domestic cooking not studied here) can be distinguished from wildfire charcoals requires further study. The normal distribution of reflectance values centred around $1.4 \%$ Ro may be distinctive of charcoal production in a clamp (Fig. 6). However, samples from additional clamp experiments are needed to test this hypothesis and these need to include both additional random sampling and samples from exterior and interior areas. It would however be possible to determine between low temperature anthropogenic activities, such as in domestic hearths, which typically operate at temperatures $300-500^{\circ} \mathrm{C}$ and high temperature furnace-based activity, which may be in excess of $1,100^{\circ} \mathrm{C}$ (McDonnell 2001).

Bias in the archaeological record

Although charcoal is more likely to be preserved than wood, charring does not 'guarantee' survival in the archaeological record. Charcoal yield is affected by the temperature, duration and atmosphere of the fire, the moisture content of the wood and the species of wood used as fuel (Smart and Hoffman 1988).

Woods with higher moisture content tend to produce more fragile charcoals (Minnis 1987). However, in our experiments, this variable was reduced by using wood from the same tree which had been seasoned for the same period of time. According to Olson (1991), the species of wood burnt will also affect charcoal yield; denser woods tend to produce higher quality charcoal. According to Howkins (1994), the charcoal of some species is also more robust than others. For example, Quercus is more robust than Corylus. Quercus would have been more likely to be used in high temperature processes as it provided sustained high temperatures (Howkins 1994).

In the laboratory experiments reported here, oxygen could be easily excluded from the samples and all the wood was converted to charcoal with no ashing. However, in field situations, complete combustion (and therefore loss of sample) is more likely, especially in the external or hotter central parts of an open fire (Smart and Hoffman 1988). Charcoal is therefore most likely to remain in the parts of a fire where oxygen has been excluded (such as where it has been enclosed by ash) or in kilns and furnaces where processes are carried out under reducing conditions. Our laboratory experiments also showed that very high temperature charcoals were smaller and more brittle than those produced at low temperatures (Table 1, Fig. 1) and therefore would be more fragile and more likely to break up prior to, or after, deposition. 
Many factors affect preservation of charcoal in the archaeological record (Smart and Hoffman 1988). The rate of sedimentation affects how long the sample is exposed before it is buried. Soil moisture and the type of deposit can subject samples to wetting and drying and to the action of freeze-thaw processes. The depth of overburden, i.e. the depth below the surface where the charcoal is located, will determine how likely the sample is to be damaged by trampling, burrowing etc. Higher temperatures also produce lighter charcoals (Fig. 2) and these charcoals would be more easily transported by water biasing the assemblage (Nichols et al. 2000). This must be taken into account when studying charcoal assemblages; an understanding of the manner in which the charcoal entered the context is paramount.

Braadbaart et al (2009) demonstrated that incubation for 147 days in $\mathrm{KOH}(\mathrm{pH}=12.5)$, to represent alkaline environments found within soil, lowers reflectance values. However, we infer from the data supplied that the maximum implied temperature shift at $5 \%$ Ro would be $60^{\circ} \mathrm{C}$ and below $3.5 \%$ Ro the maximum is $40^{\circ} \mathrm{C}$. Therefore, this does not affect our ability to use reflectance to distinguish between high $\left(>800^{\circ} \mathrm{C}\right)$ and low $\left(\leq 500^{\circ} \mathrm{C}\right)$ temperature anthropogenic processes.

The amount of charcoal recovered will also depend on sampling technique. Sometimes charcoals, especially large pieces, are picked by hand during excavation. Bulk samples will also often be taken and then flotation used to separate out the charcoal and other charred plant remains from the rest of the sample (Smart and Hoffman 1988; personal observation LCM). In the former case, smaller charcoal pieces are likely to be ignored while in the latter case fragmentation may occur.

Bias in the archaeological record is more likely to be related to temperature of charring rather than re-charring because the brittleness of charcoal is related to the highest temperature it reached at any point in the charring process (Table 1). Brittle charcoal is more vulnerable to breakage at any point in the preservation, collection and study processes. Therefore, more brittle, high temperature charcoals are likely to be biased against in the archaeological record or overlooked in the samples. McParland et al. (2009) analysed three size fractions of archaeological material recovered from the furnace of a Roman hypocaust system and found that the smallest $(<2 \mathrm{~mm})$ size fraction yielded the highest reflecting charcoals. Therefore, in the field and laboratory, small fragments $(\leq 2 \mathrm{~mm}$ ) of brittle charcoal should never be ignored. The recognition of abundant high reflectance, hence high temperature, charcoals is important because these are characteristic of anthropologic use in industrial processes (as seen in the iron smelting and bronze casting assemblages; Fig. 6).

\section{Conclusions}

Laboratory-produced oak charcoals show increasing reflectance with increasing charring temperature (from $0.26 \%$ to $6.72 \%$ Ro at temperatures $300-1100^{\circ} \mathrm{C}$ for 1 and $24 \mathrm{~h}$ ). These data are in agreement with other studies of laboratory-charred woods.

When laboratory charcoals, which have been produced at $300-800^{\circ} \mathrm{C}$, are re-charred at higher temperatures, they take on the higher reflectance values of the highest temperature experienced. Reflectance of re-charred charcoal is not constrained by the temperature of the first period of charring. Therefore, reflectance values of archaeological charcoals provide data on the range of temperatures reached in the highest temperature situation to which the charcoal was exposed.

Wildfire assemblages of charcoals show a spread of reflectance values, always including very low values and with a range of higher values (never greater than $3.8 \%$ Ro in this study and typically less than $1.85 \%$ Ro) depending on the nature of the fire. Anthropogenic-produced charcoal from a charcoal clamp shows a narrow range of reflectance values, which overlap with those of wildfire charcoals, with a maximum $2.33 \%$ Ro. High reflectance values $(>6.5 \%$ Ro $)$ would indicate high temperatures of formation $\left(>1,100^{\circ} \mathrm{C}\right)$ and in archaeological contexts such as hearths indicate intentional generation of high temperature burns by humans for industrial processes (metallurgy). It is likely that these high temperatures were achieved using charcoal fuel rather than wood because of its higher calorific value and this use therefore represents re-charring. This can be recognised in a distribution plot of reflectance values as all values from high temperature processes (iron smelting and bronze casting) lie above that of the maximum value of the charcoal production clamp.

Re-charring should not prevent the botanical identification of charcoals because tissue structure (Fig. 5) remains intact. The high temperature charcoals that indicate industrial processes are less likely to be well preserved because of their brittle nature. Therefore, in the field and laboratory, small fragments $(\leq 2 \mathrm{~mm})$ of brittle charcoal should never be ignored. High temperature charcoal is also lighter and small pieces of light charcoal are also more likely to be transported and potentially lost from the sample.

The low temperature process of charcoal production yields a charcoal assemblage with reflectance values similar in some respects to those from natural wildfires and the same may be true for domestic hearths, ovens and kilns not studied here. However, charcoal productions may be distinguishable by the normal distribution of the reflectance values and the lack of very low reflectance charcoals. In contrast, assemblages representing use of charcoal fuel show reflectance values constrained between the tempera- 
ture of charcoal fuel production and the maximum temperature reached in the industrial process, in this case metallurgy. Therefore, charcoal assemblages from industrial processes like metallurgy are readily distinguishable from wildfire charcoals and from anthropogenic charcoal production as a fuel in a traditional earth clamp.

Acknowledgements We would like to thank the Wealden Iron Research Group for information about experimental iron production; Paul Pinnington and Jon Roberts for their 'traditional charcoal burning' course at the Weald and Downland Open Air Museum, Chichester; Dr Tim Young and Neil Burridge for providing the experimental iron and bronze casting charcoal samples; Dr Tom Kemp, keeper of Bagley Wood Sawmill, St Johns College, Oxford for supply of wood; Kevin D'Souza and Ian Steel for technical support; Mike Craker for wood preparation; Sharon Gibbons for management of the palaeontology laboratory; and Ria Mitchell for management of SEM facilities. Funding for the project, provided by English Heritage, Archaeoscape and Royal Holloway, University of London, is gratefully acknowledged. ACS acknowledges funding from the Royal Society for the purchase of the ovens, support of the USGS and Deborah Martin for the collection of the Hayman wildfire samples and support of the Kavli Institute of Theoretical Physics and Jon Keeley (USGS) for the collection of the Zacca wildfire samples. We thank the Leverhulme Trust for funding for work on the Tilford (Frensham) fire. Simon Nobes and James Giles of Natural England (then English Nature) gave permission for work at Thursley and we thank them for their time and support at the site. Rachel Brain, Tony Brain, Sharon Gibbons, Selena Smith and David Steart assisted with charcoal collections at Thursley. Comments from two anonymous referees were very helpful in improving the manuscript.

\section{References}

Bayley J, Dungworth D, Paynter S (2001) Archaeometallurgy centre for archaeology guidelines. English Heritage, London

Bird MI (2006) Radiocarbon dating of charcoal. In: Elias SA (ed) The Encycl quart Sci. Elsevier, Amsterdam, pp 2950-2957

Braadbaart F, Poole I (2008) Morphological, chemical and physical changes during charcoalification of wood and its relevance to archaeological contexts. J Archaeol Sci 35:2425-2674

Braadbaart F, Poole I, van Brussel AA (2009) Preservation potential of charcoal in alkaline environments: an experimental approach and implications for the archaeological record. J Archaeol Sci 36:1672-1679

Bustin RM, Guo Y (1999) Abrupt changes (jumps) in reflectance values and chemical compositions of artificial charcoals and inertinite in coals. Int J Coal Geol 38:237-260

Christensen, LB, Jensen, SF, Lund Johansen, AL, Johansen, PR, Lerager, S (2007) House 1: Experimental Fire and archaeological excavation in Rasmussen, M (ed) Iron Age Houses in flames. LEJRE Historical-Archaeological Centre: Lejre. Studies in Technology and Culture 3:42-135

Czimczik CI, Preston CM, Schmidt MWI, Werner RA, Schulze ED (2002) Effects of charring on mass, organic carbon, and stable carbon isotope composition of wood. Org Geochem 33:1207-1223

Dillmann P, L'Héritier M (2007) Slag inclusion analyses for studying ferrous alloys employed in French medieval buildings: supply of materials and diffusion of smelting processes. J Archaeol Sci 34:1810-1823

Figueiral I, Mosbrugger V (2000) A review of charcoal analysis as a tool for assessing quaternary and tertiary environments: achieve- ments and limits. Palaeogeogr, Palaeoclimateol, Palaeoecol 164:397-407

Gale WKC (1981) Ironworking. Shire, Oxford

Gebhard R, Häusler W, Moosauer M, Wagner U (2004) Remnants of a bronze age rampart in upper Bravaria: a Mössbauer study. Hyperfine Interact 154:181-197

Gonzales-Vila FJ, Tinoco P, Almendros G, Martin A (2001) Pyrolysis-GC-MS analysis of the formation and degradation stages of charred residues from lignocellulosic biomass. J Agric Food Chem 49:1128-1131

Graham R T (Ed) (2003) Hayman fire case study. Gen. Tech. Rep. RMRS-GTR-114. Ogden, UT: U.S. Department of Agriculture, Forest Service, Rocky Mountain Research Station. 396 p.

Guo Y, Bustin RM (1998) FTIR spectroscopy and reflectance of modern charcoals and fungal decayed woods: implications for studies of inertinite in coals. Int J Coal Geol 37:29-53

Hammes K, Smernick RJ, Skjemstad JO, Herzog A, Vogt UF, Schmidt MWI (2006) Synthesis and characterisation of laboratory charred grass straw (Oryza sativa) and chestnut wood (Castanea sativa) as reference materials for black carbon quantification. Org Geochem 37:1629-1633

Hayman R (2008) Charcoal iron making in nineteenth-century Shropshire. Econ Hist Rev 61:80-98

Henderson J (2000) The science and archaeology of materials - an investigation of inorganic materials. Routledge, London

Hollingdale AC, Krishnan R, Robinson AP (1999) Charcoal production: a handbook. Eco-logic, Bristol

Howkins C (1994) Trees herbs and charcoal burners. Chris Howkins, Weybridge

Jackson DA, Ambrose TM, Pacitto AL, Woods PJ, Tylecote RF, Biek L, Hartley BR, Hartley KF, Jenkins F, Goodburn R, Esmonde Cleary AS, Butcher SA, Bayley J, Charlesworth D, Anderson FW, Cook A, Jones R, Evans R, Arthur R (1978) Excavations at Wakerley, Northants, 1972-75. Britannia 9:115-242

Jones TP, Scott AC, Cope M (1991) Reflectance measurements and the temperature of formation of modern charcoals and implications for studies of fusain. Bull Soc Geol France 162: $193-200$

Keeley JE (2006) South Coast Bioregion. In: Sugihara NG, van Wagtendonk JW, Shaffer KE, Fites-Kaufman J, Thode AE (eds) Fire in California's Ecosystems. University of California Press, Los Angeles. pp 350-390

Livingstone-Smith A (2001) Bonfire II: the return of pottery firing temperature. J Archaeol Sci 28:991-1003

McDonnell JG (2001) Pyrotechnology. In Brothwell DR, Pollard AM (eds) Handbook of archaeological sciences. Wiley, Chichester, pp 493-505.

Marguerie D, Hunot J (2007) Charcoal analysis and dendrology: data from archaeological sites in north-western France. J Archaeol Sci 34:1417-1433

McParland LC, Collinson ME, Scott AC, Steart DC, Grassineau NV, Gibbons SJ (2007) Ferns and fires: experimental charring of ferns compared to wood and implications for palaeobiology, palaeoecology, coal petrology, and isotope geochemistry. Palaios 22:528-538

McParland LC, Hazell Z, Campbell G, Collinson ME, Scott AC (2009) How the Romans got themselves into hot water, temperatures and fuel types used in firing a hypocaust. Env Archaeol 14:172-179

Minnis PE (1987) Identification of wood from archaeological sites in the American Southwest, I: keys for gymnosperms. J Archaeol Sci 14:121-131

Nichols G, Cripps JA, Collinson ME, Scott AC (2000) Experiments in waterlogging and sedimentology of charcoal: results and implications. Paleogeogr Palaeoclimatol Palaeoecol 164: $43-56$ 
Olivier L, Kovacik J (2006) The 'Briquetage de la Seille' (Lorraine, France): proto industrial salt production in the European Iron Age. Antiquity 80:558-566

Olson SD (1991) Firewood and charcoal in classical Athens. Hesperia 60:411-420

Rundel PW (1983) Impact fire on nutrient cycles in Mediterraneantype ecosystems with reference to chaparral. In: Kruger FJ, Mitchell DT, Jarvis JUM (eds) Mediterranean-type ecosystems: the role of nutrients. Springer, New York, pp 192-207

Scott AC (2000) Pre-Quaternary history of fire. Palaeogeogr, Palaeoclimatol, Palaeoecol 164:281-329

Scott AC, Jones TP (1991) Microscopical observations of recent and fossil charcoal. Microsc anal 24:13-15

Scott AC, Jones TJ (1994) The nature and influence of fires in Carboniferous ecosystems. Palaeogeogr, Palaeoclimatol, Palaeoecol 106:91-112

Scott AC, Glasspool IJ (2005) Charcoal reflectance as a proxy for the emplacement temperature of pyroclastic flow deposits. Geology 33:589-592
Scott AC, Glasspool IJ (2007) Observations and experiments on the origin and formation of inertinite group macerals. Int J Coal Geol 70:55-66

Scott AC, Cripps JA, Collinson ME, Nichols GJ (2000) The taphonomy of charcoal following a recent heathland fire and some implications for the interpretation of fossil charcoal deposits. Palaeogeogr, Palaeoclimatol, Palaeoecol 164:1-31

Scott AC, Sparks RSJ, Bull ID, Knicker H, Evershed RP (2008) Temperature proxy data and its significance for the understanding of pyroclastic density currents. Geology 36:143-146

Smart TL, Hoffman ES (1988) Environmental interpretation of archaeological charcoal. In: Hastorf CA, Popper VS (eds) Current paleoethnobotany: analytical methods and cultural interpretations of archaeological plant remains. Prehistoric archeology and ecology. University of Chicago Press, Chicago, pp 167-196

Turner WES (1956) Studies of ancient glass and glass making process, part V: raw materials and melting process. J Soc Glass Technol 40:277-300 